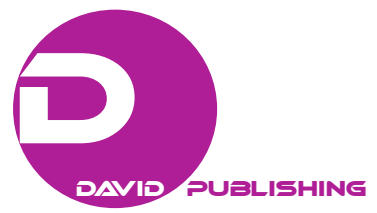

\title{
An Exploratory Study on Journalistic Professionalism and Journalism Education in Contemporary China
}

\author{
Baohui Shao \\ Hebei University, Hebei Province, China \\ Qingwen Dong \\ University of the Pacific, Stockton, CA, USA
}

\begin{abstract}
Journalism education and the journalism industry have boomed in the past twenty years in China, however, journalism school graduates are not highly welcomed by media organizations. In order to examine issues and challenges facing journalism education, this study conducted an in-depth interview with practicing journalists and journalism educators through a lens of journalistic professionalism. This paper finds that their perceptions are focusing on expertise, commitment, responsibility but eschewing journalistic autonomy deliberately with respect to journalistic professionalism and concentrating on rigid journalism knowledge without "professional" or practical ability with respect to journalism education. Limitation and suggestions for future research are also provided.
\end{abstract}

Keywords: Chinese journalistic professionalism, journalism education, journalism education challenges

\section{Introduction}

Journalism education is usually regarded as a crucial component of the profession of journalism (Harless, 1990; Johnstone et al., 1976; Weaver et al., 2003; Windahl \& Rosengren, 1978), which can improve the level of journalistic professionalism among journalists (Wilensky, 1964; Wu \& Ding, 2007; Zhang, 2011). Ideally, journalistic professionalism is good to consolidate journalists' credibility and social prestige (Deuze, 2004; Wu, 2009) and can lead journalists to "the best practices of journalism" (Mustafa, 2010).

Journalistic professionalism has emerged in the western countries in the 19th century (O'Boyle, 1968), particularly nurtured in America (Dennis \& Merrill, 2006; Guo, 1999). In fact, it has been a concept central to American journalists since the late 19th century (Beam, 1990; Wu et al., 1996). To some extent, journalistic professionalism has been widely transported around the world both through the power of US and British international news agencies (Waisbord, 2013) as well as their innumerable institutional links, training programs and educational curricula provided to many other parts of the world (Golding, 1977). In China, the concept of journalistic professionalism has also been accepted widely by both journalism scholars (Guo, 1999; Lu \& Pan, 2002; Yang, 2013) and working journalists (Lin, 2008; Xiang, 2010).

On the other hand, journalism education plays an important role in cultivating potential professional journalists. There were two styles of cultivating potential journalists developed through history: One was the college-model, and the other was the apprentice-model (Qiu, 1998; Wu, 2002). Even in journalism education

Baohui Shao, Associate Professor, School of Journalism \& Communication, Hebei University.

Qingwen Dong, Professor \& Chair, Department of Communication, University of the Pacific. 
nowadays, there are indeed two competing models between "preparing students for the industry and the study of general knowledge pertinent to higher education" (Zhou \& Zhong, 2006). Definitely the aims of both are undoubtedly similar to develop graduates with the professional ability to meet the demands of society, especially news media.

Journalism education and the journalism industry have boomed in recent decades in China. According to the Department of Higher Education of Chinese Education Ministry, 661 universities or colleges were able to afford journalism courses in 2005, up from only 66 in 1994 (He, 2005). By the end of 2011, the number of journalism schools reached 975 and nearly 200,000 undergraduates majored in journalism in universities (Wu $\&$ Wang, 2012). It can be estimated that tens of thousands of graduates would get their journalism degrees each year. However, the total number of journalists with a press card granted by the government was only 180,000 in November 2006 (Zhou, 2007). Obviously, the supply of journalism graduates exceeded the demands of the news media. On the contrary, graduates with journalism degrees are not highly welcomed by news organizations, which prefer graduates with other majors (Zhang, 2011; Wu \& Ding, 2007; Liu, 2001), including literature, history, philosophy, politics, law, economy, and sociology (Chen, 2006). Therefore, it is worth observing journalism education through a lens of journalistic professionalism, which is still in the forming process in China (Wu \& Ding, 2007; Lu \& Pan, 2002).

The purpose of this study is to provide a better understanding of the problems of Chinese journalism education from the perspective of journalistic professionalism.

\section{Literature Review}

Journalistic professionalism thrived in liberal capitalism (Clement \& Chan, 2007) and liberal ideology (Wu, 2009), especially connecting to a democratic market society in its inception (Schudson, 1978). Journalistic professionalism was first advocated for in the 19th century and was widely accepted by journalists as "the excellences to which journalists aspire" in America (Weaver \& Wilhoit, 1996). To some extent, journalistic professionalism has been used as "a 'common language' and ideological commitment within the subculture of journalists in various countries," including China (Lee et al., 1997).

Indeed, many scholars and commentators argued that for most of the twentieth century, journalism could or could not be considered a profession (Dennis \& Merrill, 2006; Weaver et al., 2007). The better choice for the inquiry, however, might be concluded by Weaver and Wilhoit (1986) that journalism "is of a profession but not in one". It is true that many of the investigations of journalistic professionalism have halted at this point (Schudson \& Andson, 2009).

Journalistic professionalism can be studied through three levels: an individual level, an organizational level, and an industrial level (Qian, 1998; Beam, 1990; Weaver et al., 2007). It should be noted that there are fewer investigations at an organizational level except Beam's (1990). At an industrial level, Wilensky (1964) suggested an evaluation model to define professionalization of journalism, consisting of five successive stages: (1) it begins to pursue an area of work as a full-time occupation; (2) it establishes a training school; (3) a professional association is formed; (4) representatives of the occupation agitate politically to win legal support for the right to control their work; and (5) the professional association promulgates formal codes of ethics. American sociologists, Johnstone, Slawski and Bowman (1976) concluded that journalism in the United States could be considered a profession. According to these five stages of journalism becoming established and accepted as a profession, it can be said that journalism has become a profession in China as well. 
At an individual level, it is generally accepted that professional-orientated journalists should desire a job that uses their professional skills and knowledge, that contributes an essential service, and that permits free expression, but they should not place much emphasis on the salary, security, and prestige (McLeod \& Hawley, 1964). Nayman (1973) synthesized four basic attributes of journalistic professionalism that are essential to a profession: expertise, autonomy, commitment, and responsibility. Specifically, journalistic expertise means specialized knowledge and skills for the profession; journalistic autonomy allows journalists to utilize their judgment without outside interference; journalistic commitment indicates journalists devoting their lifetime to the profession; and journalistic responsibility refers to journalists' fiduciary relationship to society (Nayman, 1973; Lo, 1995).

Definitely a rudimentary form of journalistic professionalism has been found to bud in China (Pan \& Chan, 2003). According to Lu and Pan (2002), journalistic professionalism has become a key matter of concern for Chinese journalists and educators. Yang (2013) even asserted that the Chinese media reform has been affected not only by the ideological liberalization but also by the western concept of journalistic professionalism. However, it is worth noting that the concept was academically introduced into Mainland China in the late 1990s (Guo, 1999).

Even though there was a remarkable lack of consensus about journalistic professionalism (Beam, 1990; Wu, 2009), Guo (1999) as a Chinese scholar outlined journalistic professionalism that incorporated two points: objective journalism and the specific status and function of journalists. Li (2004) explained journalistic professionalism as serving the public with accurate, comprehensive, objective and balanced information. More importantly, the majority of the local Chinese scholars were interested in adapting this concept for the Chinese context. For example in China, journalistic professionalism should be spread by reflecting the Chinese Community Party's and the Chinese People's views and interests first and foremost (Hou \& Zhao, 2003; Wu, 2006). However, there were also oppositions that journalistic professionalism could not be available in a Chinese context because of journalism's lack of both journalistic freedom and public service motivation (Rui, 2010; 2012). Different opinions about journalistic professionalism proved that different journalistic ideologies coexisted in contemporary China.

From the perspective of the phenomenological approach, professionalism is used and defined in everyday life as members of an occupation in a specific social context (Freidson, 1994; Dingwall, 1976; Qian, 1998). The approach rejects a strict and formal definition of a profession as an artifact (Freidson, 1994), but studies the way members of an occupation put the term in everyday usage (Dingwall, 1976). Apparently, the phenomenological approach is the least-formalized tradition and it is not an objectified, idealized description of a social phenomenon (Beam, 1990). Therefore, though journalistic professionalism might become a point of reference for China's journalists in which they view their craft (Pan et al., 2008), there can be different perceptions on journalistic professionalism among working journalists as well as journalism educators in China.

Chinese journalism education and research began in 1918 when the Institute of Journalism of Peking University was founded. Journalism education in China has a history of nearly 100 years by far. Before the foundation of the People's Republic of China in 1949, journalism education was influenced greatly by the United States (Li, 2003; Liu, 2001; Ni, 2000). The Department of Journalism of Yenching University in Beijing was funded by the American Christian church; the Department of Journalism of St. John University in Shanghai was established by American professor F.L. Hawks Pott; Xu Baohuang, "the founder of Chinese 
journalism education" at Peking University, graduated with degrees in journalism and economics from the University of Michigan in the United States (Fang, 1998). It should be noted that journalism education in universities established strong connections with the journalism industry, for example, Shao Piaoping - the chief editor of Jing Pao — was employed as teaching staff at the Institute of Journalism of Peking University.

After 1949, Chinese journalism education began to copy the former Soviet model, emphasizing first the correct political attitudes that the news media should be the propaganda tool of the communist party and government (Li, 2003; Liu, 2001; Mao \& Pan, 2014). The main courses included Marxist-Leninist theories, newspaper's mass work, public propaganda (Ding, 1997) as well as the Soviet journalism history and theory (Li $\&$ Liu, 2005). Despite experiencing several reforms later on, journalism education had been influenced strongly by the former Soviet model (Li, 2003) and still kept the ideology of "throat and tongue" journalism (Liu, 2001). Majority journalism schools were practice-oriented and based on journalistic skills training (Wu, 2002) and key journalism courses were composed of three parts: journalism history, journalism theory, and journalism practice (Zhang, 2011). Undoubtedly, journalism education has cultivated a large number of journalistic talents and met the basic demands of journalism development in China, especially for the recent decades of the reform and opening policy ( $\mathrm{Li}, 2003)$.

Journalism education however, has faced a certain amount of criticism and required a fundamental reform, especially in today's information era. Besides its over-expansion, in general, Chinese journalism education was criticized for its shortage of teaching staff, lack of facilities, rigid curriculum system, and weaknesses of internship (e.g., Gao, 2013; Liu, 2014; Zhang, 2010; Wu \& Wang, 2012; Wang \& Li, 2005; Wu \& Ding, 2007). More importantly, Zhang (2011) pointed out the problem that has existed for a long time in journalism education which is a lack of journalistic professionalism.

$\mathrm{Lu}$ and Yu's survey (2003) of Shanghai journalists found that journalism education was valued much lower among practicing journalists. Similarly, Wu and Ding's (2007) survey of journalists in the Zhejiang province concluded that the journalists gave relatively negative evaluations to journalism education. Only $30.2 \%$ of respondents accepted that journalism education is necessary in order to become a professional journalist.

To some extent, journalism research in China remains not only severely underdeveloped but also relatively isolated from the global context as a "closed-off model" (Pan et al., 2008). Specific theoretical frameworks and scientific methodology in relevant researches were often neglected. Also, there was a lacking of a specific concern for journalism education from the perspective of journalistic professionalism. Hence, the perception of journalistic journalism among Chinese journalists is still vague and the problem of journalism education from the perspective of journalistic professionalism is not clear. Based on the review of literature, the study proposed the following two research questions:

(1) What are the perceptions of journalistic professionalism among Chinese journalists and journalism educators?

(2) What is the assessment of Chinese journalism education from the perspective of journalistic professionalism?

\section{Methodology}

This study applied in-depth interviews to get a deep understanding of the respondents' perceptions on journalistic professionalism and problems of contemporary Chinese journalism education in universities. 
The qualitative interview was defined as an interview with the purpose of gathering descriptions of the life-world of the respondents with respect to interpretation of the meaning of the described phenomena (Kvale, 1996). The advantage of an in-depth interview is that it can be conducted with "smaller samples," but yield "the wealth of details" and "more accurate responses on sensitive issues" (Wimmer \& Dominick, 2000), in order to "deeply explore the respondent's feelings and perspectives on a subject" (Guion et al., 2011).

In fact, the face-to-face interview has long been the dominant interview technique in qualitative research in social sciences. In the past two decades, telephone interviewing has become more and more common (Opdenakker, 2006). However, with advancements of new information and communications technologies, new interviewing techniques were introduced to the field of qualitative research, for example, interview via email or e-mail interviews, MSN messenger interviews, and chat boxes interviews (Bampton \& Cowton, 2002; Opdenakker, 2006).

\section{Scope}

Generally, journalistic professionalism can be expected to be more prominent among newspaper journalists. Also, graduates with journalism degrees usually are expected to work for newspapers. Hence, the interviewees of journalists for this study were purposefully chosen from daily newspapers.

There are many differences between various districts in China due to its large territory. For example, there is a huge cultural discrepancy between northern and southern China, and there are huge economic gaps between the east, the middle, and the west in the country. This has resulted in the fact that the journalism industry is developing at different rates in different areas, and varies even in the same area (Guo, 2010). The journalism industry and journalists are disproportionally concentrated in the most developed cities in the coastal provinces, highlighted by Beijing, Shanghai, and Guangzhou (Chen et al., 1998; Lin, 2010). In this study, Beijing, the capital and the administrative, cultural and education center of China, was chosen to stand for China on the whole to some degree.

There are four types of newspapers in China: party newspapers, metropolitan newspapers (including evening newspapers), industry papers, and life-service newspapers. For this study, metropolitan newspapers were more appropriate because these newspapers are circulated not through the administrative system but through the local press market and show a relatively high level of commercialization of print media in China.

Currently, Beijing has seven metropolitan newspapers owned by three different media groups. According to their ownership and representative, three Metropolitan newspapers were purposefully chosen in Beijing. They are Beijing Evening, Beijing Youth Daily, and the Beijing News. Beijing Evening, first published in 1958, has the largest circulation in Beijing. It is also one of the four largest evening newspapers in China and the oldest metropolitan newspaper. Beijing Youth Daily has the largest subscription in Beijing and is China's second biggest newspaper group (after the Guangzhou Daily), which was first allowed to list its business operations in Hong Kong's market in 2004 as "part of a broad set of reforms aimed at commercializing China's media industry". However, the Beijing News, first published in 2003, is the first Chinese newspaper co-founded by media groups from different regions (Guangming Daily [Beijing) and Nanfang Daily Group [Guangzhou]) in China and China's first mainstream newspaper that adopted the shareholding system. The regulatory authority of the Beijing News was changed in 2011 and is now being supervised by the Publicity Department of the Beijing Municipal Committee. 
In addition, Beijing consists of the largest number of universities, including the most well-known universities in China such as Beijing University and Tsinghua University. For this study, based on the reputation of journalism schools in Beijing, the researcher contacted two universities: Renmin University of China (along the lines of the colleges of arts) and Tsinghua University (along the lines of the colleges of science). The School of Journalism at Renmin University of China, formally established in 1985 on the basis of the preceding Department of Journalism, has since developed into a nationally-acclaimed institution of teaching and research in journalism (http://rjc.ruc.edu.cn/en/21487.html); while the School of Journalism and Communication at Tsinghua University, founded in 2002, has already become one of the most prestigious top five Journalism schools in China (http://www.tsjc.tsinghua.edu.cn/publish/jcen/346/index.html).

\section{Subject}

In order to collect reliable data during the interviews, the journalists were required to have at least two years of professional experience and have different majors in universities. At best, half of those without journalism degrees, and vice versa. Hence, the journalists selected were expected to have a reasonable knowledge base with respect to the particular phenomena in terms of journalistic professionalism and journalism education. As for journalism educators, they were required to have professional experience of teaching journalism courses at relatively famous universities for more than 10 years, focusing on the topic of journalistic professionalism. Hence, the journalism educators were expected to know more about journalism education, journalistic professionalism as well as the local journalism industry.

There were eight respondents purposefully selected and interviewed for the study: six journalists and two journalism educators. Specifically, two journalists from each newspaper, among whom there were five male journalists and one female journalist. Five had university degrees, two of whom were pursuing their masters degrees as part-time post-graduate students, and two having obtained their masters degrees previously. More importantly, three were journalism graduates and three majored other subjects, such as economics, mechanics, and the arts (film). It is worth noting that one of them had the experience of studying abroad in France as well.

The two journalism educators were from the School of Journalism and Communication, Tsinghua University and the School of Journalism, Renmin University of China. They were both professors who earned journalism Ph.D. degrees. In addition, one of them had the experience of studying abroad in Canada as a visiting scholar.

\section{Procedure}

The interviews were conducted in October of 2013. The journalism educators were interviewed in their school offices separately and the journalists were interviewed in their newsrooms except one in a café nearby. The steps of in-depth interviewing were in a sequence that follows: Firstly, the journalists who had been contacted through the acquaintances in advance, were contacted by telephone to make appointments for face-to-face interviews; while the scholars were contacted directly by the researcher himself; secondly, the purpose of the study and the interview guide were explained to the respondents before conducting interviews; thirdly, the interviews were taped (with the respondents' agreements), and the time spent was ranking from 50 minutes to a little more than two hours; fourthly, all the respondents' contact information was collected (with permission) to provide opportunities for further consultations at the end of the interview, along with a warm thanks for their contribution to the study; finally, the interviews were transcribed as soon as possible. It should be noted that there were two journalists interviewed in pair because the interviewees from the same 
organizations asked to be interviewed together. All the transcripts were analyzed using the categorization analyzing technique suggested by Kvale (1996).

\section{Results}

The results indicated that the journalists' and educators' perceptions of journalistic professionalism are somewhat similar to the concept translated from the western countries, focusing on journalistic expertise, commitment, and responsibility but eschewing journalistic autonomy. In addition, it was found that Chinese journalism education could not meet the demands of the journalism industry due to its rigid journalism knowledge without "professional" or practical ability.

\section{Journalistic Professionalism}

In the new media era, citizen journalism and digital platforms have debilitated journalism as a profession (Waisbord, 2013; Witschge \& Nygren, 2009; Kur \& Essien, 2014). On the one hand, the notion that "everyone could be a reporter" has come true: Through the Internet, anyone can be a "news reporter" via blogging, tweeting, or simply by using Facebook. On the other hand, many news websites have actually allowed the audience to respond, comment, and submit their own news in text, audio and video. This has caused the existence of "boundary lines" between "insider and outsider," "professional and non-professional," "journalist and blogger" within journalism to gradually be obscured (Schudson \& Anderson, 2009). To some extent, this fact has given rise to kind of an identity crisis for journalists worldwide.

The respondents all agreed that journalism is a profession, even in an era of "everyone could be a reporter" and journalism practitioners should be professionals. They totally denied that anyone who is nearest to the news-spot or is spending much more time there would be a journalist because the journalistic job is not as easy as sending a message or a photo through social media. One journalist from Beijing Youth Daily explained the clear difference between a citizen journalist and a professional journalist:

Journalism still needs a professionally-trained team: first, a journalist knows which facts to choose; second, he knows how to present the facts; and third, he knows how to present the facts in an objective and fair style.

The perception of journalistic professionalism among the journalists focused on journalistic expertise, commitment and responsibility. Specifically, they emphasized that a profession-oriented journalist should master enough knowledge in a specific field and excellent communication skills, devoting to journalism and regarding journalistic ethics as a bottom line. One journalist from Beijing Evening stated the ideal professional journalists as such:

He has enough knowledge about a certain field and can have a clear understanding of relevant rules, issues, and the people in the field, and he has his basic judgment. Also, he can present certain things with journalistic methods. To be simple, he can understand clearly and can express clearly. Then he should be a professional journalist.

One journalist from the Beijing News gave an explanation to the "bottom line" of ethics, he said:

There is a rule. You can't abuse your “power”. For example, taking benefits from news resources or even blackmailing someone [is unacceptable]. Also, you can't do paid coverage ... this is the rule and you shouldn't touch this bottom line. As a professional journalist, it is a must to keep it.

The journalists all agreed that journalists should be committed to journalism. Despite the fact that the salary was not high, they all loved journalism. A journalist told a story that his wife often complained that he 
could not accompany her even on her birthdays. Another one observed that many young journalists stayed single because they devoted themselves to their jobs. One journalist from Beijing Youth Daily shared his opinions:

...It's his (a journalist) choice to do journalism, at least, he should be interested in journalism and respect journalism. This is very important. If he has no interests, only does typing words, it really has little significance...

Another journalist from Beijing Youth Daily stated the responsibility of a journalist is at a high level:

There is a motto in Southern Weekend [a famous weekly newspaper in China], "Understand China in the newspaper". I appreciate it. As a journalist, especially a political journalist, I think he can help the readers understand China in the rapid social transformation; he helps the reader understand how to face the transformation. What is the transformation? What does it mean? What is the responsibility of the government? What is the responsibility of a citizen? I think it is (political) journalists' responsibility to present clearly. It isn't just a presentation of a piece of news.

However, nearly all the journalists mentioned less about journalistic autonomy, which is reiterated by an educator as "the premise of journalistic professionalism". Indeed, it is a written rule for the Party to control news media in China. One journalism educator explained:

If journalism lacks autonomy, at least relative autonomy, it is a luxury to talk about journalistic professionalism. Obviously, in contemporary China, it is impossible for the news media to be independent of the Party or the government... so under the existing media system, it is available to only discuss about journalistic practice, focusing on the techniques.

Obviously, journalistic professionalism is not just transplanted from one country to another, especially countries with different political, economic, and social settings. Despite the fact that China usually shows its own "Chinese characteristics", one journalism educator expressed the vision optimistically:

Journalistic professionalism is a western concept and based on the premise of journalistic freedom. But China has a different situation. You can't explain journalism in China by using only a journalistic professionalism perspective. Nonetheless, (journalistic) professionalism can to some extent change the ideology of Chinese journalists. It functions kind of "reconstructing and improving".

Hence, the results answered the first research question with the respondents' understanding of journalistic professionalism as well as its premise and possible future in China.

\section{Journalism Education}

Journalists or educators, with or without journalism degrees, nearly all disagreed that journalism education could cultivate eligible talents to meet the industry's demands. Actually, several extreme cases emerged recently that news organizations had recruited a batch of new staff without journalism certificates (Liu, 2001). One journalist without a journalism degree from the Beijing News even claimed, "Looking at those who can do journalism better, nearly none of them majored in journalism”. Another journalist without a journalism degree from Beijing Youth Daily explained:

There is a voice from our society that journalism education at the university level, especially at a masters level, is not that necessary. If a person likes writing, and thinks deeply, he can become a good journalist by practice. Of course, this is somewhat extreme, but journalism education cannot meet the public expectation. It's a fact.

One journalism educator shared this point by saying:

For a journalist, it's absolutely important for a potential journalist to know about society and understand the society 
well, to learn the skills to interview and communicate...there's no need [for all above] to get a higher certificate...if he has a high-school diploma, then no problem, he can do the report because it's straightforward...journalists can also be trained on the job, it's not that difficult.

Specifically, the three journalists with journalism degrees tended to show their disappointments on journalism education. One from Beijing Youth Daily pointed out:

Based on my experience, I think undergraduates with other majors [without journalism degrees] would be more appropriate to become journalists. This is because journalism requires a comprehensive quality. Whether you have curiosity, insight, and a tenacious fighting spirit, it doesn't depend on your journalism certificate; and whether you can do journalism professionally, it doesn't depend on your journalism certificate, either.

On the other hand, the three journalists without journalism degrees tended to show confidence in their ability to do journalism well. They claimed "Accumulation of journalistic knowledge and practice is extremely important" and "Techniques belong to journalism but the idea is beyond journalism". One journalist without a journalism degree shared his personal experience:

To be honest, I was ever feeling inferior because I didn't major in journalism. But after some time, I realized learning is an acquired process. Also there is a training program in the newspaper organization. Understanding organizational culture and its standards of value, I feel that I have made some progress gradually. I think I can do journalism well, even better than others [who have journalism degrees]. Now I am a senior journalist, the organization has awarded me that title.

As to advantages of journalism graduates, the respondents acknowledged that journalism school students can begin their work quickly at the first however. One educator emphasized that journalism education could, theoretically, provide journalist students with "a set of (journalistic) professional principles and a set of professional techniques". In fact, as one journalist with an economics degree said, journalism students could put themselves in the best place via the written test of recruitment provided by news organizations because the journalism students know the 5W1H (who, when, where, what, why and how) for news writing.

However, when mentioning disadvantages of the journalism education, the standardized model was criticized by the journalists, saying that the advantage at the beginning might become a big constraint later on. One journalist with a journalism degree clarified:

...I majored in journalism, but I only understand some superficial rules about journalism. For example, feature is longer than news. But there is something important beyond journalism education...journalism education has become a fixed model and it constrains students in how to observe and present the world.

A journalist without a journalism degree stated further:

...when, where, who, you must introduce these facts first, then he said, she said and so on, to some extent, it has made the writing style somehow dull, but journalistic job does need more creativity.

Besides, the journalists pointed out that there is actually no specific profession in journalism education such as politics and economy. A journalist, based on her own experience, said, he could not get certain knowledge in a particular field in his journalism major and on the contrary, techniques of interviewing and news writing he got from journalism education can be learned quickly from journalistic practice. Another journalist with a journalism degree shared his experience that he felt lucky that he got his second degree in law by himself when he was studying at the university. More importantly, it can be very difficult to learn particular knowledge deeply on the job. One journalist with a journalism degree gave more explanation: 
If one (a journalist) studied journalism at a university, he might feel he knows everything, but his knowledge was superficial, not deep. When he is working for a daily, the pace of life is increasing, he'll be busy pursuing news reporting, and then he can't have time or a quiet attitude to learn more. This is a big problem. Of course it's much better he could learn more when he was a (journalism) student.

Furthermore, the respondents thought that journalism graduates lacked practical ability that is important for journalists. Generally, it can be credited to the gap between journalism education and journalism practice. Just as one journalist pointed out, practical requirements are "much higher than (journalism) textbooks". The journalists with journalism degrees and educators listed a few key problems with journalism schools. For example, many journalism educators lacked journalistic practice, who became a journalism teacher once he received his master or Doctoral degree; journalism textbooks were also separated from journalistic practice, which still provided cases which happened decades ago; journalism students lacked practical opportunities in universities and through internships which often become formalistic.

The respondents did not agree on whether a journalist needs a higher degree, for example, a master's degree. Four journalists and one educator objected strongly, while the other two journalists and educator supported this idea. The supporting reasons were that if one person pursues a higher degree with the aim of improving himself, then he can get more from the studying process. One journalism educator stated:

Usually, if one obtains a higher education and more knowledge, one would understand things more deeply and he would be trained professionally more easily.

It should be noted that higher education in China has become popularized education since the late 1990s. However, many young people wanted a higher degree with the aims not to improve themselves with knowledge but to create opportunities of finding better jobs. In fact, one journalist respondent reported that there have been fewer and fewer undergraduates but more and more graduates in the newspaper he was serving for. Additionally, another journalist showed his worries about journalists who had higher degrees:

Maybe the higher degree one person has, the more idealistic he would be. His opinions might become extremely contradictive to the reality. He thinks the world should be "white is white" and "black is black". But the world is somewhat grey, and we are living in this grey world...we know that only knowledge from textbooks is superficial. They would all face this problem.

The two journalism educators did not agree on cultivating journalism students with regard to journalistic professionalism, which reflected the arguments on journalism education worldwide. One insisted:

There seems to be no causal correlation between formal journalism education and journalistic professionalism. It doesn't necessarily mean one has received journalism education or more education then he can have his level of professionalism improved. You can only say he can get more knowledge about journalism history, journalism theory and journalism practice.

The other showed his optimistic attitude, however, by saying:

Theoretically, if one journalist has received a higher education, he should get at least two kinds of advantages: one is that his expressing ability would be improved, [on] presenting events or opinions; the other is he would understand the concept of journalistic professionalism...But in the context of China, it might highlight the contradiction of attribute of media (mouthpiece of the Party and government) and pursuit of journalistic professionalism.

Hence, the results provided adequate answers to the second research question as well. However, it should be noted that the respondents focused on the existing journalism education in China and their opinions were 
somewhat general and sweeping. To be optimistic, according to the educators, with the transformation of the journalistic model and even the media system, journalism education can be expected to improve the level of journalistic professionalism among journalists in China.

\section{Discussion}

The results indicated that both the Chinese journalists and journalism educators agreed that journalism should be a profession even in an era of "everyone can be a reporter", and journalism practitioners should be professionals. They emphasized journalistic expertise, commitment, and responsibility as the core elements of journalistic professionalism in their everyday usage. Specifically, they highlighted expert knowledge in a particular field beyond journalism, excellent interpersonal communication skills, devoting oneself to the profession, and regarding journalistic ethics as a bottom line. However, the Chinese journalists and educators alike kept somewhat realistic attitudes and avoided discussing more about journalistic autonomy because of the fact that there was a written rule for the governing party to rein in news media in the country. Nonetheless, it could be concluded that the Chinese journalists and educators held somewhat similar perceptions with respect to the concept translated from western counties.

The findings also indicated that the Chinese journalists and educators almost agreed that contemporary journalism education was not that satisfying. They only acknowledged that journalism graduates might start their work quickly at the onset. On the contrary, they pointed out that rigid journalism knowledge could limit the creativity of graduates in their journalistic practice later on; additionally that there was no profession in journalism education beyond surface skill-training; and journalism school graduates usually lacked practical ability. Furthermore, they tended to disagree that journalists should pursue higher degrees. However, the educators had different opinions on the function of journalism education in terms of journalistic professionalism.

The implication of the study was that journalistic professionalism and professional journalism education in China are still in the midst of professionalization of journalism. On the one hand, the spread of journalistic professionalism would be more dependent on media systems in the country, and that the concept had been adapted with "Chinese characteristics," focusing on journalistic expertise, commitment, and responsibility, but eschewing journalistic autonomy. On the other hand, most respondents agreed that Chinese journalism education could not meet the demands of the journalism industry. To some extent, Chinese journalism was in crisis and needed an urgent reform, professionally. However, journalism education reform would be a systematic and complicated project due to a specific context.

The limitation of the study was the relatively narrow scope of only metropolitan newspapers in Beijing. Besides, the study was limited to the low number of the respondents. Therefore, future researchers should carry out relevant studies by applying more respondents within a broader scope, for example, a questionnaire approach, in order to get abundant data and establish an agreement on the reform of improving Chinese journalism education.

\section{References}

Bampton, R., \& Cowton, C. J. (2002). The e-interview. Retrieved December 4th, 2013, from http://eds.a.ebscohost.com/ehost/pdfviewer/pdfviewer?sid=146c282c-a31b-404e-a239-1641b4ae08ba\%40sessionmgr4003\& vid=2\&hid=4203

Beam, R. (1990). Journalism professionalism as an organizational-level concept. Journalism Monographs, 121, 1-43. 
Chen, C. (2006). What major favored by journalism industry. News and Writing, 7, 16.

Chen, C., Zhu, J. H., \& Wu, W. (1998). The Chinese journalists. In D. Weaver (Ed.), The global journalists: News people around the world. Cresskill, New Jersey: Hampton Press.

Clement, Y. K. S., \& Chan, J. M. (2007). Professionalism, politics and market force: Survey studies of Hong Kong journalists 1996-2006. Asian Journal of Communication, 17(2), 148-158.

Dennis, E. E., \& Merrill, J. C. (2006). Media debates: Great issues for the digital age (4th ed.). Belmont, CA: Thomson Wadsworth.

Deuze, M. (2004). Journalism studies beyond media: On ideology and identity. Ecquid Novi, 25(2), 275-293.

Ding, G. (1997). How to determine the training targets and curriculum of university journalism education? The Journalism University, 4, 70-73.

Dingwall, R. (1976). Accomplishing profession. Sociological Review, 24(2), 331-349.

Fang, H. (1998). The cradle of Chinese journalism and journalism education. Chinese Journalist, 5, 26-27.

Freidson, E. (1994). Professionalism reborn: Theory, prophecy, and policy. Cambridge: Polity Press.

Gao, G. (2013). Thoughts on the reform of Chinese journalism education under the trend of media convergence. Journalism Collection, 29, 139-145.

Golding, P. (1977). Media profesionalism in the Third World: The transfer of an ideology. In J. Curran, M. Gurevitch, \& J. Woollacott (Eds.), Mass communication and society. London: SAGE Publication.

Guion, L. A., Diehl, D. C., \& McDonald, D. (2011). Conducting an in-depth interview. Retrieved September, 23, 2013, from http://edis.ifas.ufl.edu/fy393

Guo, Q. (2010). On the current situation and trends of newspaper industry in China. Retrieved October 1st, 2012, from http://media.people.com.cn/GB/22100/120097/120099/13045071.html

Guo, Z. (1999). Public supervision and professionalism of western journalists. International Press Circle, 5, 32-38.

Harless, J. (1990). Media ethics, ideology, and personal constructs: Mapping professional enigmas. Journal of Media Ethics, 5(4), 217-232.

He, Z. (2005). The four problems and strategies of journalism education. Chinese Journalist, 6, 22-23.

Hou, Y., \& Zhao, Z. (2003). An introduction to western journalism. Contemporary Communications, 4, 55-57.

Johnstone, J. W. C., Slawski, E. J., \& Bowman, W. W. (1976). The news people: A sociological portrait of American journalists and their work. Urbana: University of Illinois Press.

Kur, J. T., \& Essien, C. F. (2014). Do new media make the practice of journalism more or less a profession? New Media and Mass Communication, 21, 56-63.

Kvale, S. (1996). Interviews: An introduction to qulitative research interviewing. California: Sage Publication.

Lee, C. C., Chan, J. M., \& Lee, P. S. N. (1997). Professionalism among Hong Kong journalists in comparative perspective. In B. T. McIntye (Ed.), Mass media in the Asian Pacific (pp. 5-13). Hong Kong: Short Run Press.

Li, J. (2003). On Chinese journalism education history. Beijing: Xinhua Press.

Li, L. (2004). Introduction to journalism. Shanghai: Fudan University Press.

Li, L., \& Liu, Y. (2005). Interview with Professor He Zihua. Retrieved from http://edu.sina.com.cn/y/news/2005-11-02/180447457.html

Lin, B. (2008). Hu Shuli and journalistic professionalism. Retrieved July 13, 2013, from http://www.infzm.com/content/13930

Lin, F. (2010). A survey report on Chinese journalists in China. The China Quarterly, 202, 421-434.

Liu, H. (2001). On crisis and opportunity of Chinese journalism education. Journalism Quarterly (Winter), 88-91.

Liu, L. (2014). On problems and strategies of Chinese journalism education. Net Friend World, 2, 79.

Lo, V. H. (1995). Professionalism among journalists: Concept and scale. Communication Research Monographs, 2, 1-47.

Lu, Y., \& Pan, Z. (2002). Imaging professional fame: Constructing journalist professionalism in China's social transformation. Mass Communication Research, 71, 17-59.

Lu, Y., \& Yu, W. (2003). Attitudes on journalistic roles and ethics among news people. News Reporter, 4, 8-11.

Mao, Z., \& Pan, Y. (2014). Xiamen University journalism Cafe (3) Dr. Cao Lixin on the Soviet Union Model and Chinese journalism industry twentieth century. Journal of International Journalism, 12, 174-176.

McLeod, J. M., \& Hawley, S. E. (1964). Professionalization among newsmen. Journalism Quarterly, 41(4), 529-538.

Mustafa, K. A. (2010). Commentary: Teaching "best practices" of journalism in Malaysia. Asia Pacific Media Educator, 20, 177-182.

Nayman, O. B. (1973). Professional orientations of journalists: An introduction to communicator analysis studies. Gazette, 19, 195-212. 
Ni, N. (2000). Development and characteristics of Chinese journalism education. Journal of International Communication, 5, $11-14 ; 43$.

O'Boyle, L. (1968). The image of the journalsit in France, Germany, and England, 1815-1848. Comparative Studies in Society and History, 10(3), 290-317.

Opdenakker, R. (2006). Advantages and disadvantages of four interview techniques in qualitative research. Forum: Qualitative Social Research, 7(4), Art. 11.

Pan, Z., \& Chan, J. M. (2003). Shifting journalistic paradigms: How China's journalists assess "Media exemplars". Communication Research, 30(6), 649-682.

Pan, Z., Chan, J. M., \& Lo, V. H. (2008). Journalism research in Greater China. In M. Loffelholz, \& D. Weaver (Eds.), Global Journalism research: Theories, methods, findings, future. Malden, USA: Blackwell Publishing.

Qian, Y. (1998). Study on conceptual structure and indicators of journalistic professionalism (Unpublished Doctoral dissertation, National Chengchi University, Taiwan).

Qiu, P. (1998). Journalism industry and journalism education. Press Circles, 1, 18-19.

Rui, B. (2010). Description? Regularization? Journalistic professionalism in Chinese journalism and communication practice. Journalism and Communication, 1, 56-62.

Rui, B. (2012). Journalistic professionalism: A professional privilege ideology-Rethinking on journalistic professionalism in Chinese journalism and communication practice. Journal of International Communication, 12, 72-77.

Schramm, W. (1957). Responsibility in mass communication. New York: Harper \& Brothers.

Schudson, M., \& Anderson, C. (2009). Objectivity, professionalism, and truth seeking in journalism. In K. Wahl-Jorgensen, \& T. Hanitzsch (Eds.), The handbook of journalism studies (pp. 88-101). New York: Routledge.

Shudson, M. (1978). Discovering the news: A social history of American newspapers. New York: Basic Books.

Soloski, J. (1990). News reporting and professionalism: Some constraints on the reporting of the news. Media Culture \& Society, 11(4), 207-228.

Tuchman, G. (1978). Making news: A study in the construction of reality. New York: Free Press.

Waisbord, S. (2013). Reinventing professionalism: Journalism and news in global perspective. Cambridge: Polity Press.

Wang, Y., \& Li, P. (2005). Looking at professionalization of journalism based on the problems of journalism education. Education and Vocation, 34, 73-74.

Weaver, D. H., Beam, R. A., Brownlee, B. J., Voakes, P. S., \& Wilhoit, G. C. (2007). The American Journalist in the 21 st century: U.S. news people at the down of a new millennium. Mahwah, New Jersey: Lawrence Erlbaum Associates.

Weaver, D., \& Wilhoit, G. C. (1986). The American journalist: A portrait of U.S. news people and their work. Bloomington: Indiana University Press.

Weaver, D., \& Wilhoit, G. C. (1996). The American journalists in the 1990s. Mahwah, New Jersey: Lawrence Erlbaum Associates, Publishers.

Weaver, D., Beam, R., Brownlee, B., Voakes, P., \& Wilhoit, G. C. (2003). The American journalist in the 21st century: Key findings. Proceedings from the Association for Education in Journalism and Mass Communication, Kansas City, MO.

Wilensky, H. L. (1964). The professionalization of everyone? American Journal of Sociology, 70(2), 137-158.

Wimmer, R. D., \& Dominick, J. R. (2000). Mass media research: An introduction. Belmont, CA: Wadsworth.

Windahl, S., \& Rosengren, K. (1978). Newsmen's professionalization: Some methodological problems. Journalism Quarterly, 55, 466-473.

Witschge, T., \& Nygren, G. (2009). Journalistic work: A profession under pressure? Journal of Media Business Studies, 6(1), 37-59.

Wu, F. (2009). Studies on professionalism. Beijing: China Renmin University Press.

Wu, F., \& Ding, Z. (2007). Journalism education and the construction of the ideas of professional journalism. Journal of Zhejiang Universtity (Humanities and Social Sciences), 37(6), 128-137.

$\mathrm{Wu}, \mathrm{G}$. (2006). The history development and current dilemma of journalistic professionalism. Journal of Social Science of Hunan Normal University, 35(6), 75-78.

$\mathrm{Wu}, \mathrm{G}$. (2006). The history development and current dilemma of journalistic professionalism. Journal of Social Science of Hunan Normal University, 35(6), 75-78.

$\mathrm{Wu}, \mathrm{T}$. (2002). The introduction of communication studies and the reform of Chinese journalism education. Journalism Quarterly (Spring), 25-28.

Wu, T., \& Wang, D. (2012). From content challenge to system innovation: The way to the reform of journalism education. 
Journal of Southwest University for Nationalities (Humanities and social sciences edition), 7, 150-154.

Wu, W., Weaver, D., \& Johnson, O. V. (1996). Professional roles of Russian and U.S. journalists: A comparative study. Journalism and Mass Communication Quarterly, 73(3), 534.

Xiang, X. (2010). Southern Weekly: Maintain and create journalistic professionalism. Media, 7, 32-34.

Yang, B. (2013). A possible choice of dominated journalism outlook in contemporary China: Developmental journalistic professionalism. Journal of International Communication, 3, 82-90.

Zhang, C. (2011). On realistic significance of journalistic professionalism education. Journal of Sichuan Normal University (Social Sciences Edition), 38(6), 162-166.

Zhang, Z. (2010). On problems and strategies of Chinese journalism education. Time Education, 11, 265.

Zhou, K. (2007). Journalism education over-expanded in Chinese universities. China Youth Daily.

Zhou, S., \& Zhong, X. (2006). Preface. In X. Zhong, \& S. Zhou (Eds.), Community and change: Perspectives on journalism \& communication education. Beijing: Communication University of China Press. 